Dorota Konopka

\title{
ZNACZENIE ZAUFANIA I KOOPERACJI W WYMIARACH LOKALNYCH WIDZIANE Z PERSPEKTYWY 25 LAT SAMORZĄDNOŚCI W POLSCE
}

\section{Wprowadzenie}

25 lat samorządności terytorialnej w III Rzeczpospolitej jest już wystarczająco długim okresem, który uzasadnia postawienie pytania o postęp, jaki się dokonał w tym okresie w sferze samodzielnego współzarządzania swoimi sprawami przez społeczności lokalne i regionalne w Polsce, a także perspektywy rysujące się przed nią w ciągu najbliższych lat.

Historia samorządności w Polsce jest nierozerwalnie związana $\mathrm{z}$ dwiema podstawowymi wartościami: wolnością i wspólnotą (wspólnotowością). Wolnością, którą Jacek Kuroń rozumiał jako budzenie się do wspólnego działania ${ }^{1}$, a wspólnotą - jako niezbędną przestrzenią do rozwoju osobowości, moralnego dojrzewania, uczenia się brania odpowiedzialności za siebie i członków grupy. Idea wspólnotowości powiązana jest ściśle z lokalnością. Dla zrozumienia pojęcia lokalności należy sięgnąć do samych podstaw istnienia społeczeństwa. Jej podstawowe właściwości polegają na współtworzeniu systemu więzi integrujących członków danej społeczności oraz wspólnoty norm, wartości i przekonań wynikających z pokrewieństwa, sąsiedztwa, typu wykonywanych zajęć lub innych elementów jednoczących ludzi² Lokalność rozumiana w szerszym kontekście to ważny element układu odniesienia, czyli strategii budowania tożsamości. K.Z. Sowa lokalizm definiuje jako „względną autonomię oraz upodmiotowienie konkretnych społeczności lokalnych w zakresie gospodarczym, społecznym i kulturalnym w ramach szerszego układu społeczno-przestrzennego i politycznego"3.

1 J. Żakowski, Kuszenie Jacka Kuronia, „Polityka” 25 czerwca 2004, nr 26(2458).

2 A. Majer, Lokalność w cieniu globalizacji, „Annales Universitatis Mariae Curie-Skłodowska Lublin-Polonia" 2011, Vol. XXXVI, 2, Sectio 1, s. 28.

3 K.Z. Sowa, Zmierzch i odrodzenie lokalizmu, w: Społeczności lokalne. Teraźniejszość i przyszłość, red. B. Jałowiecki, K.Z. Sowa, P. Dudkiewicz, IGP UW, Warszawa 1989, s. 30. 
Spojrzenie na rozwój samorządu terytorialnego w Polsce z perspektywy historycznej (nie tylko ostatniego ćwierćwiecza) skłania do postawienia tezy, że zarówno w naukach społecznych, jak i w realizacji rzeczywistych funkcji samorządowych dokonał się na tym polu relatywnie niewielki postęp. Jeśli poszukiwać sfer, w których można taki postęp odnotować, to na pierwszy plan wysuwają się nie tyle realne modele społeczne, ile zmiany świadomościowe. W tym właśnie obszarze warto więc przede wszystkim upatrywać krytycznych czynników postępu i sukcesu dalszych reform polskiej samorządności terytorialnej.

\section{Jaki kapitał społeczny?}

Uwarunkowania historyczne w postaci wieloletnich lat zaborów i 45-letnie podporządkowanie polityczne Związkowi Radzieckiemu nie zrodziło wśród Polaków szacunku dla własnego państwa i reguł demokratycznego współdziałania. Między innymi z tego powodu w polskiej kulturze społecznej brakuje poczucia priorytetu wspólnego państwa. Z pokolenia na pokolenie raczej umacniały się dotychczas postawy antypaństwowe. Duża część społeczeństwa polskiego w zetknięciu z wolnością i demokracją charakteryzowała się często nieufnością („syndrom wroga”), pazernością, niskim poziomem zmysłu państwowego, niechęcią do aktywności w różnego rodzaju organizacjach społecznych, koncentrowaniem się na życiu rodzinnym ${ }^{4}$.

Janusz Czapiński ${ }^{5}$ stwierdził, że Polska przez 25 lat rozwijała się w sposób „molekularny", czyli Polacy rozwijali się przede wszystkim za pomocą aktywności indywidualnej, budując kapitał społeczny tzw. wiążący (bonding social capital), określany jako eksluzywny, opisany przez Roberta Putnama ${ }^{6}$. Był to też wynik „zachłyśnięcia się" wolnością w pierwszym etapie transformacji, który objawiał się specyficzną formą "prymitywnego liberalizmu”. Taki rodzaj kapitału społecznego (wiążącego) polega na formowaniu „więzi społecznych z osobami homogenicznymi pod względem socjoekonomicznych charakterystyk"; głównie spośród rodziny, klanu czy znajomych7.

4 W. Kieżun, Patologia transformacji, Poltext, Warszawa 2012, s. 347-348.

5 http://analizy.mpips.gov.pl/images/stories/publ_i_raporty/DS2013/Raport_glowny_Diagnoza_Spoleczna_2013.pdf [dostęp 8.12.2014].

6 Zob. R.D. Putnam, Bowling Alone. The Collapse and Revival of American Community, Simon\&Schuster, New York 2000 [wyd. polskie: R.D. Putnam, Samotna gra w kręgle. Upadek i odrodzenie wspólnot lokalnych w Stanach Zjednoczonych, tłum. P. Sadura, S. Szymański, Wydawnictwa Akademickie i Profesjonalne, Warszawa 2008].

7 K. Growiec, Kapitał społeczny. Geneza i społeczne konsekwencje, Wydawnictwo Szkoły Wyższej Psychologii Społecznej „Academica”, Warszawa 2011, s. 24. 
Konsekwencjami kapitału wiążącego, nazwanego przez Alejandro Portesa wręcz kapitałem negatywnym, jest wykluczenie osób nienależących do grupy oraz ograniczenie możliwości wyboru i działania osób go tworzących ${ }^{8}$. Dostęp do sieci społecznych zbudowanych na zasadach kapitału wiążącego jest utrudniony, a nawet niemożliwy. Jednostki takich grup charakteryzują się niskim stopniem zaufania do każdej „inności" i posiadają skłonność do nawiązywania relacji z osobami podobnymi do nich samych. Jest to czysty paradoks związany z siłą słabych więzi ${ }^{9}$. Ten rodzaj kapitału społecznego ma przede wszystkim negatywne konsekwencje dla życia społecznego - umacnia lokalizm i ogranicza dialog, kreując sytuację zamknięcia się jednostki lub grupy w wąskiej i ograniczonej przestrzeni lokalnej oraz nieufności wobec grup spoza lokalnego terytorium.

Do tego rodzaju barier rozwoju kapitału społecznego nawiązuje w swoich badaniach Katarzyna Growiec, analizując zasoby kapitału społecznego polskiego społeczeństwa, a przede wszystkim konsekwencje różnych rodzajów kapitału społecznego dla funkcjonujących norm i postaw, które kształtują życie społeczne w Polsce. Wskazuje na istnienie sprzężenia zwrotnego między różnymi typami sieci społecznej - kapitałem pomostowym i kapitałem wiążącym oraz odpowiednio zaufaniem i nieufnością. Growiec podsumowuje, że to kapitał wiążący i związane z nim normy społeczne decydują o jakości polskiego życia społecznego. Towarzysząca mu nieufność, wrogość do innych i oczekiwanie zawiedzenia zaufania jest ciągle cechą charakterystyczną polskiego społeczeństwa.

Zdaniem Growiec w Polsce panuje amoralny familizm z tendencją do amoralnego indywidualizmu ${ }^{10}$. Amoralny familizm cechuje nastawienie na natychmiastowe, łatwo wymierne korzyści i efekty, które są oceniane wyżej i praktycznie eliminują długofalowe planowanie i osiąganie perspektywicznych celów. Kultury familistyczne są pozbawione wartości kolektywnych i norm o charakterze uniwersalnym, obca jest im troska o dobro wspólne i kategorię interesu społecznego ${ }^{11}$.

Z kolei M.S. Lipset i G.S. Lentz wysuwają przypuszczenie, że amoralny familizm oddziałuje negatywnie na rozwój gospodarczy kraju. Na potwierdzenie tego przypuszczenia wskazują, iż narody, które zajmują wysoką pozycję na skali swoiście określanego familizmu, osiągają niski poziom dochodu na jednego mieszkańca ${ }^{12}$.

8 A. Portes, The Two Meanings of Social Capital, „Sociological Forum” March 2000, Vol. 15, No. 1, s. 1-13.

9 K. Growiec, op.cit., s. 24.

10 Ibidem, s. 174

11 A. Lewicka-Strzałecka, Korupcja i zaufanie, http://www.annalesonline.uni.lodz.pl/archiwum/2007/ 2007_01_lewicka_strzalecka_211_219.pdf [dostęp 13.12.2014].

${ }_{12}$ S.M. Lipset, G.S. Lenz, Korupcja, kultura i rynki, w: Kultura ma znaczenie, red. L.E. Harrison, S.P. Huntington, Zysk i S-ka, Poznań 2003, s. 199. 


\section{25 lat samorządności (?)}

Jacek Kuroń, będąc współtwórcą samorządności we współczesnej Polsce, w idei wspólnego działania poprzez samorządność widział aktywne współuczestnictwo (współdziałanie, partycypację) w całym jego procesie: od etapu planowania, poprzez zarządzanie, monitorowanie celów, aż do refleksji nad tym, co się dotychczas udało zmienić na lepsze i zastanowienia, co dalej trzeba zmieniać, aby to ulepszyć1 ${ }^{13}$.

Celem tak rozumianej partycypacji, gdzie aktywność jest mniej sformalizowana, a w debacie publicznej tworzy się swobodna przestrzeń do krytycznej refleksji, są wypracowywane innowacyjne rozwiązania, odpowiadające na potrzeby społeczeństwa. Uczestnicy działań partycypacyjnych są gotowi do wprowadzenia zmian - zarówno w perspektywie indywidualnej, jak i grupowej. Jacek Kuroń tę ideę próbował urzeczywistniać w małych grupach. Dla niego była to również swoista metoda socjalizacyjna, pedagogiczna. Trudności w zastosowaniu tej metody powstają jednak wówczas, gdy o aktywnym uczestnictwie jest mowa w realnym kontekście państwa, gminy czy powiatu i podejmowane są próby jej praktycznego zastosowania.

Dla wielu Jacek Kuroń był kontrowersyjnym, utopijnym idealistą, który poruszał się w świecie fundamentalnych wartości, ale jednocześnie był oderwany od rzeczywistości. Dla innych - „powrót do języka wartości wydaje się kluczowy dla budowania społeczeństwa połączonego więzami i solidarnością" ${ }^{14}$. Staje się podstawą wspólnotowości, co ma szczególne znaczenie w czasach wszechogarniających kryzysów - w tym również współczesnych kryzysów demokracji. Kiedy tę ideę wprowadzimy do mechanizmu animowania rozwoju lokalnego i regionalnego, wówczas znaczenia nabiera zarządzanie wielopoziomowe. Oznacza ono uspołecznienie władzy publicznej. To przede wszystkim wynika z kultury dialogu, którego deficyt jest w Polsce wyjątkowo głęboki, co w perspektywie jest najpoważniejszym zagrożeniem rozwoju ${ }^{15}$.

Z kolei samorządność według Jerzego Regulskiego, jednego ze współtwórców reformy samorządowej w Polsce w latach $1989-1990^{16}$, to prawo do stosowania

13 A. Dents-Sadura, Współpraca i działanie grupowe: o metodzie pedagogicznej Jacka Kuronia, w: Kuroń. Przewodnik Krytyki Politycznej, Wydawnictwo Krytyki Politycznej, Warszawa 2014, s. 114.

14 M. Syka, Kuroń budzi nas do działania, w: ibidem, s. 277.

15 Narastające dysfunkcje, zasadnicze dylematy, konieczne działania. Raport o stanie samorzadności terytorialnej w Polsce, Wydawnictwo UE w Krakowie, Małopolska Szkoła Administracji Publicznej w Krakowie, Kraków 2013, s. 33; zob. też: J. Gardawski, Dialog społeczny w Polsce. Teoria, historia, praktyka, MPiPS-Oficyna Wydawnicza SGH, Warszawa 2009 oraz Praca, społeczeństwo, gospodarka. Między polityka a rynkiem, red. J. Osiński, Oficyna Wydawnicza SGH, Warszawa 2011.

16 Współtwórcą reformy był także Michał Kulesza, mianowany pełnomocnikiem rządu do spraw reformy na stanowisku podsekretarza stanu w Urzędzie Rady Ministrów. 
różnorodnych rozwiązań, w zależności od lokalnych potrzeb i warunków ${ }^{17}$. Regulski stwierdza: „dajmy ludziom decydować, ten gorset prawny jest niepotrzebny”" Powstaje jednak pytanie, czy ta postulowana przez niego idea faktycznie weszła w życie? Dziś coraz wyraźniej widać, że nie, gdyż logika procesów samorządowych była (i jest) inna - legalistyczna i polityczna.

Reforma samorządowa rozpoczęta w 1989 r. nie uwzględniała podstawowego i bardzo ważnego czynnika: znaczenia wyborów „prawdziwych”, czyli bezpośrednich, których coraz bardziej stanowczo domagają się obywatele. W ostatnim stuleciu wartości obywatelskich broniła zbiorowa moc dokonywania zmian przez jednostkę. Obecnie wyborcy mogą tylko w niewielkim stopniu decydować o tym, kto będzie zasiadał w rządzie i samorządzie terytorialnym. Ich głosy wciąż służą jedynie do „wyboru” partii słusznie rządzącej ${ }^{19}$. Ordynacja wyborcza ${ }^{20}$, która jest uchwalona równolegle z ustawą powiatową i wojewódzką, jest bowiem ordynacją zgodną z zapisem konstytucyjnym o tzw. ordynacji proporcjonalnej.

Praktyka wyborcza pokazuje, że ta koncepcja jest zupełnie niezgodna z podstawową zasadą demokracji - decydowania przez większość. Szczególnie jest to istotne, gdy idea demokracji partycypacyjnej, deliberatywnej (omawiana szeroko wśród teoretyków i praktyków na świecie i w Polsce) w toku jej implementacji sprawia wiele trudności, a często jest zbiorem pustych frazesów ${ }^{21}$. Na iluzję związaną z ideą lokalnej partycypacji obywatelskiej w polskiej rzeczywistości trafnie wskazują Barbara Gąciarz i Jerzy Bartkowski, stwierdzając: „Największym zagrożeniem dla rządzenia partycypacyjnego jest potraktowanie go jak instrumentu manipulacji społecznej, służącego do narzucenia partykularnych celów działań rozwojowych przez biurokrację regionalną lub lokalną, bądź też przez grupy interesu wykorzystujące swoją przewagę organizacyjną lub komunikacyjną. Innym zagrożeniem jest rytualizacja działań partycypacyjnych, która zwykle jest dodatkowym efektem zawłaszczenia mechanizmów partycypacyjnych przez wybrane środowiska"22.

17 Zob. J. Regulski, Życie splecione z historia, Ossolineum, Wrocław 2014.

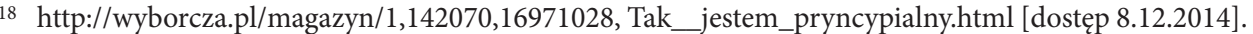

19 I. Krastew, Demokracja nieufnych. Eseje polityczne, Wydawnictwo Krytyki Politycznej, Warszawa 2013, s. 19; zob. też: J. Flis, Złudzenia wyboru, Wydawnictwo Uniwersytetu Jagiellońskiego, Kraków 2014; autor dogłębnie analizuje polski system wyborczy, ukazując formalne reguły niepasujące do społecznych wyobrażeń.

20 Ustawa z dnia 18 lipca 1998 r. o ordynacji wyborczej do rad gmin, rad powiatów i sejmików województw, DzU 1998, nr 95, poz. 602.

21 K.W. Frieske, Polowanie na jednorożca: demokratyczna administracja publiczna, „Samorząd Terytorialny" 2014, nr 1-2(277-278), s. 5.

22 B. Gąciarz, J. Bartkowski, Samorząd a rozwój. Instytucje - obywatele - podmiotowość, IFiS PAN, Warszawa 2012, s. 58 . 
Społeczeństwo (w tym społeczności lokalne czy regionalne) jako koalicja interesów jest obrazem niekompletnym, bo społeczeństwo jest również wspólnotą moralną. Jednym z podstawowych elementów wspólnoty moralnej jest „zaufanie, czyli oczekiwanie uczciwego postępowania innych wobec nas oraz lojalność, czyli powinność nienaruszania zaufania, jakim obdarzają nas inni, i wywiązywanie się z podjętych zobowiązań” ${ }^{23}$.

Po zaprzysiężeniu rządu premiera Tadeusza Mazowieckiego we wrześniu 1989 r. już po kilku miesiącach - 8 marca 1990 r. powstała ustawa o samorządzie terytorialnym. Ustalono $\mathrm{w}$ niej racjonalny schemat statycznej struktury administracji z dwuszczeblową administracją terenową gmin i województw. Warto podkreślić, że nie istniała jeszcze wówczas całościowa koncepcja transformacji systemu administracji - w nawiązaniu do konstytucji, która została uchwalona dopiero w $1997 \mathrm{r}$. Na tę niesłychanie ważną okoliczność zwraca uwagę Witold Kieżun, który pisze, że „nie można sprawnie budować izolowanych części całości bez planu [...]. Dlatego elementarną zasadą budowania czy reformowania wielkiego systemu administracji publicznej jest priorytet posiadania wizji całości i dynamiki jego zachowań z pełną świadomością struktury wewnętrznych więzi”"24.

Dalszymi krokami w procesie reformowania administracji terenowej było powołanie w sierpniu 1990 r. 254 urzędów rejonowych jako pomocniczych jednostek organów wojewódzkich. Faktycznie stały się one jej drugim szczeblem, stając się terenowymi jednostkami rządowej administracji ogólnej. Obejmowały one swoim zakresem działania od kilku do kilkunastu gmin. Od 1990 r. rozpoczął się więc szybki rozwój struktury państwowej administracji, który niestety ukazał narastającą antydecentralistyczną tendencję tworzenia resortów z ministerstwami bezpośrednio kierującymi administracją terenową, która nie była zespolona $\mathrm{z}$ administracją specjalną i urzędami wojewódzkimi.

W tym okresie jest też wyraźnie widoczny długotrwały trend reformy administracyjnej nastawionej na rozbudowę aparatu centralnego, tworzącą stromą, wieloszczeblową oraz kosztowną i archaiczną strukturę polskiej administracji. Regułą sprawności wieloszczeblowych organizacji jest budowa płaskich struktur z małą liczbą szczebli organizacyjnych ${ }^{25}$. Jest to kolejna koncepcja niezgodna z podstawową zasadą współczesnej demokracji „mniej centralnej administracji rządowej, więcej samorząd-

23 P. Sztompka, Zaufanie. Fundament społeczeństwa, Znak, Kraków 2007, s. 36.

24 W. Kieżun, op.cit., s. 280.

25 Zob. P. Drucker, Praktyka zarządzania, MT Biznes, Warszawa 2003; w założeniach projektu ONZ dotyczących Europy Wschodniej czytamy, że „struktura administracji państwowej i samorządowej powinna być prosta, $\mathrm{z}$ tendencją do minimalizowania liczby szczebli i jednostek". 
ności i oddolnej inicjatywy indywidualnej”26. Sytuacja zmieniła się dopiero od 1 stycznia 1999 r. z chwilą powołania samorządowych powiatów i samorządowych wojewódzkich urzędów marszałkowskich. Zmniejszono wówczas liczbę rodzajów jednostek administracji specjalnych, bezpośrednio zarządzanych z centrum. Trafnie ocenił tę sytuację Jerzy Hausner: „To była po prostu forma decentralizacji państwa. Ten samorząd nie był budowany na wspólnotach lokalnych"27.

W Europejskiej Karcie Samorządu Lokalnego ${ }^{28}$ ratyfikowanej przez Polskę w 1994 r. jest wyraźnie podkreślona podstawowa rola gmin. Ogłoszono to w art. 4, pkt 3: „Kierowanie sprawami publicznymi powinno, ogólnie rzecz biorąc, należeć do tych organów władzy, które są najbliżej obywatela”. Najbliżej obywatela jest urząd gminy i logicznie konstatując, w nim właśnie powinno być skoncentrowane kierowanie zasadniczą częścią spraw publicznych. Niestety, w polskim prawodawstwie brakuje formalnie ustalonych więzi pomiędzy gminą a powiatem. Komplikuje to system rozliczeń za usługi, potencjalnie tworząc sytuację konfliktogenną. Istnienie tego rodzaju zagrożenia może wpływać na mniejszą aktywność lokalną władz i społeczności lokalnych, słabą więź między nimi i skutkować brakiem tak niezbędnej wspólnotowości.

Natomiast wprowadzenie w 2002 r. do ustroju gminnego modelu prezydenckiego przyczyniło się do pogłębiania już wcześniej pojawiających się słabości w zakresie demokracji lokalnej.

\section{Kryzys zaufania i co dalej?}

Jedną z podstawowych kwestii w budowaniu społeczeństwa opartego na samoorganizacji obywateli i podejmowaniu przez nich działań w celu współtworzenia społeczności lokalnych oraz wspólnego rozwiązywania problemów społecznych jest zaufanie. Czy chaos procesu instytucjonalnego w ostatnim 25-leciu w Polsce oraz istniejące dysfunkcje systemu społecznego ${ }^{29}$, mnogość przepisów wciąż zmieniającego

\footnotetext{
26 W. Kieżun, op.cit., s. 291.

27 J. Hausner, Debata: Czy konieczne sa systemowe zmiany w funkcjonowaniu jednostek samorządu terytorialnego?, w: Sprawne państwo, Wydawnictwo UE w Krakowie, Małopolska Szkoła Administracji Publicznej w Krakowie, Kraków 2014, s. 21.

28 Europejska Karta Samorządu Lokalnego (European Charter of Local Self-Government) uchwalona została przez Europejski Parlament w Strasburgu 15 października 1985 r., ratyfikowana przez Polskę pod nazwą Europejska Karta Samorządu Terytorialnego 14 lipca 1994 r., a od 2006 r. zmieniono jej nazwę na Europejską Kartę Samorządu Lokalnego.

29 Zob. Narastające dysfunkcje, zasadnicze dylematy, konieczne działania. Raport o stanie samorządności terytorialnej $w$ Polsce, Wydawnictwo UE w Krakowie, Małopolska Szkoła Administracji Publicznej w Krakowie, Kraków 2013.
} 
się prawa ${ }^{30}$ nie wpłynęły na ogólny spadek zaufania do instytucji demokratycznych, naruszając zdolność ustroju demokratycznego do rewitalizacji? Oczywiście tak.

Zaufanie społeczne jest kluczowym i najważniejszym elementem kapitału społecznego. Jest ono niezbędne w życiu nowoczesnych społeczeństw we wszystkich sferach z uwagi na ich rosnącą złożoność, coraz szersze obszary niepewności i dominację ryzyka. Większość form społecznego kapitału, takich jak zaufanie, jest tym, co Albert Hirschman, ekonomista i filozof społeczny, nazywa zasobami moralnymi ${ }^{31}$ i rodzi się w zbiorowości jako oczekiwanie na temat regularnego, uczciwego i kooperującego zachowania innych członków wspólnoty, w oparciu o wspólnie uznane normy ${ }^{32}$. Zwłaszcza zaufanie społeczne pełni istotną rolę w funkcjonowaniu instytucji publicznych. Działalność instytucji publicznych opiera się przede wszystkim na niewypowiedzianej wprost umowie społecznej. Ludzie mają zaufanie do instytucji i ich przedstawicieli, którzy podejmują przewidywalne decyzje.

Średnia wartość uogólnionego indeksu zaufania według raportu CBOS z lutego 2014 r. pt. „Zaufanie w relacjach międzyludzkich” jest w Polsce niezmiennie ujemna. Oznacza to, że w społeczeństwie polskim nieufność i ostrożność w nastawieniu do innych przeważa nad otwartością i ufnością. Co więcej, w ostatnich dwóch latach wartość prezentowanego wskaźnika dość istotnie zmalała. Wskazuje to na dodatkową intensyfikację zdystansowania Polaków w relacjach z innymi. Obecnie grupa osób cechujących się najwyższym stopniem ostrożności w stosunkach międzyludzkich jest trzykrotnie większa niż tych, które prezentują postawę całkowitej otwartości na innych (25\% wobec $8 \%)^{33}$.

Polacy nie ufają również instytucjom publicznym. Pomimo ogólnej tendencji wzrostowej zaufania do rządu w Polsce w ciągu ostatnich czterech lat wciąż jesteśmy krajem, w którym poziom zaufania jest katastrofalnie niski. Według danych CBOS raport „Zaufanie społeczne” - marzec 2012 w Polsce urzędnicy administracji publicznej budzą niestety nadal stosunkowo wysoką nieufność wśród Polaków - 41\% (urzędnikom ufa 45\%), a jeszcze mniej zaufania mamy do rządu - 49\% (rządowi ufa $39 \%)^{34}$.

30 A. Habuda, Prawo jako instrument ograniczenia patologii w demokratycznym państwie prawnym, w: Patologie w administracji publicznej, red. P.J. Suwaj, D.R. Kijowski, Wolters Kluwer, Warszawa 2009, s. 58; dysfunkcje prawa to m.in.: przerosty formalizacji, nieracjonalnie skonstruowane instytucje prawne, blankietowe przepisy, tylko cokolwiek regulujące.

31 A. Hirschman, Against Parsimony; Three Easy Ways of Complicating Some Categories of Economic Discurse, w: Trust; Making and Breaking Cooperative Relations, red. D. Gambetta, Blackwell, Oxford 1988, s. 85.

32 F. Fukuyama, Zaufanie: kapitał społeczny a droga do dobrobytu, PWN, Warszawa-Wrocław 1997, s. 26.

33 http://www.cbos.pl/SPISKOM.POL/2014/K_029_14. PDF [dostęp 7.12.2014].

34 http://www.cbos.pl/SPISKOM.POL/2012/K_033_12. PDF [dostęp 7.12.2014]. 
Wyniki VI edycji Europejskiego Sondażu Społecznego (2002-2012) ${ }^{35}$ również dowodzą, że zmniejszyło się zaufanie do instytucji w Polsce. Podobnie jak w przypadku zaufania do innych ludzi, zwraca uwagę zahamowanie tendencji wzrostowej po 2010 r. Największym zaufaniem obdarzamy instytucje międzynarodowe (średnia ocen w skali 0-10) - Parlament Europejski $(4,22)$ i Organizację Narodów Zjednoczonych $(5,04)$. Mniejsze zaufanie deklarujemy do krajowych instytucji politycznych: systemu prawnego $(3,6)$, Sejmu i Senatu $(2,95)$, polityków $(2,22)$ oraz partii politycznych $(2,22)$.

Andrzej Rychard omawiając wyniki sondażu 6 edycji ESS, stwierdził, że „obniżenie się i tak bardzo niskiego poziomu zaufania można tłumaczyć polaryzacją sceny politycznej w Polsce. [...] Spory polityczne widoczne są już nie tylko w języku, ale pokrywają się liniami ważnych podziałów społecznych ze względu na wiek, wykształcenie, miejsce zamieszkania czy położenie ekonomiczne. Zdaniem A. Rycharda, chociaż spór polityczny nabiera ostrzejszego charakteru, to - paradoksalnie - dotyczy coraz mniejszej zbiorowości i coraz mniejszy krąg osób chce brać w nim udział. W rezultacie zaczynamy budować zaufanie w obrębie nowych instytucji społecznych, poza domeną tradycyjnej polityki i władzy"36.

Czynnikiem wpływającym na niski poziom publicznego zaufania w Polsce jest brak trwałości i przejrzystości norm porządku społecznego i prawnego. Uregulowań prawnych jest za dużo, są one skomplikowane, a wiele spośród nich jest niejednoznaczna i może być różnie interpretowana. Regulacje prawne często zmieniają się, a dostęp do informacji o nich jest utrudniony. Na pierwszy plan wysuwa się brak zaufania do wymiaru sprawiedliwości, który zawsze oznacza poważny kryzys autorytetu państwa ${ }^{37}$.

Najogólniejszym powodem spadku zaufania jest, jak się wydaje, brak jasno nakreślonych perspektyw przyszłości i związana z tym rosnąca niepewność, która powoduje powszechną nieufność i wraz z nią marazm społeczny. Nie zapewnia tego również szybko rosnący poziom technologii komunikacyjnej, która stwarza obywatelom zupełnie nowe możliwości - $\mathrm{w}$ tym protestu, prześwietlenia władzy i organizowania się. Nie są one niestety również w dostatecznym stopniu wykorzystywane ${ }^{38}$.

35 Zob. Polska-Europa. Wyniki Europejskiego Sondażu Społecznego. 2002-2012, red. P.B. Sztabiński, F. Sztabiński, IFiS PAN, Warszawa 2014.

36 P. Teisseyre, Łączy nas brak zaufania, http://civicpedia.ngo.pl/wiadomosc/955642.html [dostęp 19.02.2015].

37 D. Konopka, Kryzys zaufania a nie prawa - na przykładzie administrowania sądownictwem powszechnym $w$ Polsce, w: Kryzys prawa administracyjnego. Inflacja prawa administracyjnego, red. P.J. Suwaj, Wolters Kluwer, Warszawa 2012, s. 257-274.

38 I. Krastew, op.cit., s. 49. 
Błędy legislacyjne i organizacyjne popełnione na przestrzeni 25 lat w Polsce doprowadziły do tego, że w budowaniu społeczeństwa demokratycznego utracono najważniejszą z wartości - wspólnotowość i wiarę, że obywatele mają wpływ na coś (w rzeczywistości nie decyduje większość). Demokracja sprowadzana zostaje do „rytualnej demokracji wyborczej”39. Do takiego stanu mógł przyczynić się również obecny system ordynacji wyborczej, który - jak trafnie ujął to Kieżun - „Związany jest z ideą partiokracji, rządów, w których występuje patologiczny fenomen priorytetu interesu partyjnego nad interesem ogólnokrajowym" ${ }^{\text {"40 }}$. Zmiana ordynacji wyborczej wydaje się jednym z podstawowych etapów rewitalizacji zaufania do administracji lokalnej, publicznej.

Obok systemowych zmian w funkcjonowaniu JST, które mogą przyczynić się do wzrostu zaufania i lepszej współpracy administracji z obywatelami, interesującym kierunkiem poszukiwań drogi odbudowy zaufania do administracji publicznej w Polsce jest obszar, który określam jako glokalizację zaufania publicznego. Obecnie państwo i jego instytucje na szczeblach lokalnych i regionalnych stopniowo przestają być wystarczająco aktywnym czynnikiem integrującym istniejące tam społeczności i w dostatecznym stopniu przeciwstawiającym się narastającym zagrożeniom. To, co jeszcze nie tak dawno temu było dostępne dla wszystkich, obecnie uległo komercjalizacji, a następnie prywatyzacji i staje się zamknięte i dostępne tylko dla niektórych. W miejsce dotychczasowych wartości wspólnych pojawiają się wartości, które stają się dostępne tylko dla nielicznych. Coraz szybsze kurczenie się przestrzeni publicznej jest przede wszystkim spowodowane wdrażaniem neoliberalnej wizji organizacji polskiego społeczeństwa ${ }^{41}$.

Natomiast glokalizacja zaufania to koncentracja na tworzeniu wartości publicznej w ścisłym kręgu zaufania, budowana na podstawie silnych i gęstych relacji w przestrzeni publicznej ${ }^{42}$, rozciągającej się pomiędzy poziomem życia prywatnego (grupy pierwotne) a poziomem makro (formalne instytucje państwa). Konstrukcją nośną niniejszego modelu teoretycznego jest pojęcie "dobra publicznego" (public good) Mancura Olsona, w którym dobro publiczne definiowane jest jako „niewyłączność,

39 P. Żuk, Zmiana jest możliwa i konieczna, „Le Monde Diplomatique Polska”, „Dolnośląski Dodatek Kulturalny" 15 grudnia 2014, $\mathrm{nr} 2$, s. VIII.

40 W. Kieżun, op.cit., s. 329.

41 P. Żuk, op.cit., s. VIII.

42 Zob. D. Konopka, Glokalizacja zaufania publicznego jako nowa kategoria socjoekonomiczna, „Kwartalnik Nauk o Przedsiębiorstwie" 2015, nr 3(36), s. 20-29; D. Konopka, Rewitalizacja zaufania do administracji publicznej w Polsce, w: Samorządność w warunkach kryzysu, red. S. Partycki, Wydawnictwo KUL, Lublin 2013, s. 216-224. 
czyli każdy członek grupy (społeczności), korzystając z tego dobra, nie odbiera go innym członkom grupy, traktując je jako „wspólny zasób” (jointness of supply) ${ }^{43}$.

Silne i gęste relacje w społeczności lokalnej budują wspólnotę dzięki wartościom, które są istotne dla mieszkańców, poprzez język daleki od biurokratyczno-prawniczej mowy. W tym kontekście powrót do języka wartości humanistycznych Jacka Kuronia wydaje się kluczowy dla budowania społeczeństwa połączonego więzami i solidarnością. Celem powinno stać się wspólne poszukiwanie podstawowych i powszechnie akceptowalnych wartości publicznych, „wartości, które są wspólne dla wszystkich podmiotów w społeczeństwie: obywateli, przedsiębiorstw, organizacji i grup nieformalnych. Jest to wynik wszystkich decyzji dotyczących alokacji zasobów podjętych przez wszystkich interesariuszy w społeczeństwie jako całości" ${ }^{44}$. Juliusz Gardawski podkreśla, że bez wspólnych wartości i wzajemnego zaufania nie dojdzie do zainicjowania dialogu społecznego ${ }^{45}$. Administracja powinna działać jak „mistrz“ i koordynator tych sieci, które będą musiały być przejrzyste i ukierunkowane w celu wspierania optymalnego rozwoju dostarczania wartości publicznej ${ }^{46}$.

Glokalizacja zaufania publicznego oznacza też akceptację innego widzenia procesów globalizacyjnych - o wiele bardziej niż dotychczas wielowymiarowych i dopuszczających ich pluralistyczny charakter. Systemy administracji powinny stać się bardziej współpracujące, zacierając granice administracyjne. Powinny gromadzić zasoby, wiedzę i doświadczenie (know-how) wszystkich istotnych podmiotów publicznych, prywatnych i obywatelskich w ścisłym kręgu. Współcześnie lokalność zmienia swoje oblicze. Koncentracja na budowaniu lokalnych sieci zaufania w nowym kontekście glokalizacyjnym to jednocześnie poszukiwanie lokalnych form tożsamości wspólnoty, tak niezbędnej w turbulentnym świecie zmian.

Spadek zaufania do instytucji publicznych doprowadza również do sytuacji, w której jednostki i organizacje przestają sobie radzić w tak niezrozumiałej i coraz mniej czytelnie zorganizowanej przestrzeni społecznej. Warto zauważyć, że paradoksalnie poziom zaufania $\mathrm{w}$ równie dużym stopniu zależy od posiadanej wiedzy na temat danego stanu rzeczy, instytucji lub osoby, jak też od stopnia niewiedzy na ten temat ${ }^{47}$.

43 M. Olson, The Logic of Collective Action, Harvard University Press, Cambridge, MA 1965, s. 14.

44 M. Botterman, J. Millard, E. Horlings, C. van Oranje, M. van Deelen, K. Pedersen, Wartość dla obywateli. Wizja zarzadzania publicznego w 2020 roku, Raport stworzony dla Komisji Europejskiej, Grudzień 2008, s. 5, http://www.opsi.org.pl/index.php?option=com_k ${ }^{2} \& v i e w=i t e m \& l a y o u t=i t e m \& i d=1137 \& I t e m i d=50$ [dostęp 11.12.2014].

45 J. Gardawski, op.cit., s. 405, http://www.dialog.gov.pl/gfx/mpips/userfiles/_public/Broszury/Juliusz_ Gardawski.pdf

46 M. Botterman, J. Millard, E. Horlings, C. van Oranje, M. van Deelen, K. Pedersen, op.cit., s. 7.

47 A. Herman, D. Konopka, Rola zaufania w zarzadzaniu wartościa w warunkach rosnacej niepewności, w: Metodologiczne aspekty zarządzania wartościa przedsiębiorstwa, red. E. Urbańczyk, A. Gąsior, 
Zaufanie to swoistego rodzaju wiara, która w takim samym stopniu jest uzależniona od wiedzy jak i jej braku. Jeżeli zatem zaufanie we współczesnym świecie musi wynikać również ze swoistej wiary ${ }^{48}$, to czy drogą odbudowy stopnia zaufania nie będzie zaufanie normatywne? Nawet zagorzały zwolennik zaufania opartego na wiedzy,

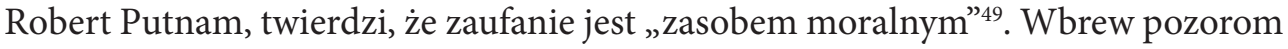
to właśnie zaufanie normatywne dostarcza racjonalnego uzasadnienia dla współdziałania z innymi ludźmi i dążenia z nimi do kompromisów. Zaufanie normatywne nie jest relacyjne. Jeżeli zaufanie byłoby warunkowane odwzajemnionym zaufaniem (lub racjonalnym oczekiwaniem tego zachowania), nie byłoby wcale zaufaniem, ale zachowaniem opartym na oczekiwaniach co do zachowania innych. Może nie powinniśmy mówić wówczas o kryzysie zaufania społecznego, ale o braku skutecznej i efektywnej komunikacji w społecznościach lokalnych i nie tylko? Zaufania normatywnego (otwartości), współpracy oraz skutecznej i efektywnej komunikacji należy uczyć od najmłodszych lat, przekazując je w procesie socjalizacji pierwotnej oraz wtórnej.

Po 25 latach budowania samorządności w Polsce społeczeństwo jako całość oraz jego części lokalne i regionalne stoi przed koniecznością realizacji kolejnego etapu rozwojowego, czyli budowy tzw. kapitału pomostowego (bridging social capital) ${ }^{50}$. Ma on charakter inkluzywny, gdyż włącza do sieci relacji społecznych osoby z różnych środowisk oraz różnych „społecznych molekuł - mikrostruktur” - w myśl zasady „mniej egoizmu, więcej współpracy”. Ten typ kapitału jest przede wszystkim związany z zaufaniem i umiejętnościami współpracy z osobami, których nie znamy. Jego istotą jest kooperacja i współdziałanie w ramach grupy formalnej, która możliwa jest dzięki powszechnemu uznaniu reguł i zasad przyjętych w ramach szerszej społeczności. Budowa kapitału pomostowego powinna więc bardziej zmierzać w kierunku umacniania „kultury zaufania” i normatywnych ideałów ufności. Dzięki temu może on stać się bardziej istotnym czynnikiem, który pozwala wyzwalać i mobilizować ludzkie działania, uwalniając swobodną innowacyjność. Wzmacnia postawy prospołeczne i jest podstawą wszelkich procesów partycypacyjnych. Wpływa na ich własne uwarunkowania strukturalne, zwiększając stabilność normatywną, przejrzystość organizacji społecznych oraz odpowiedzialność organów władzy. Zależy to jednak od wielu czynników: spójności normatywnej, trwałości porządku społecznego,

M. Romanowska, „Zeszyty Naukowe Uniwersytetu w Szczecinie” 2012, nr 737, „Finanse, Rynki Finansowe, Ubezpieczenia" nr 56, s. 375-384.

48 Por. T. Yamigishi, M. Yamigishi, Trust and Commitment in the United States and Japan, Motivation and Emotion, 1994; A.B. Seligman, The Problem of Trust, Princeton University Press, Princeton 1997.

49 R. Putnam, Demokracja $w$ działaniu. Tradycje obywatelskie we współczesnych Włoszech, Znak, Kraków 1995, s. 265.

50 Zob. R.D. Putnam, Samotna gra..., op.cit. W tym miejscu trzeba wyraźnie podkreślić, że nie ma on nic wspólnego $\mathrm{z}$ finansowym kapitałem pomostowym. 
przejrzystości organizacji, odpowiedzialności osób i instytucji, jak również kapitału społecznego (zamożności, pewności zatrudnienia, władzy, edukacji, sieci kontaktów społecznych, wierzeń religijnych $\mathrm{i}$ in. $)^{51}$.

W takim kontekście zaufanie społeczne staje się kluczowym i najważniejszym elementem kapitału społecznego w wymiarach lokalnym i regionalnym. Jest ono niezbędne dla sprawnego funkcjonowania nowoczesnych społeczeństw - we wszystkich ich sferach $\mathrm{z}$ uwagi na ich rosnącą złożoność oraz coraz szersze obszary niepewności i ryzyka.

\section{Bibliografia}

Botterman M., Millard J., Horlings E., van Oranje C., van Deelen M., Pedersen K., Wartość dla obywateli. Wizja zarzadzania publicznego w 2020 roku, grudzień 2008, http://www. opsi.org.pl/index.php?option $=$ com_ $k^{2} \& v i e w=$ item\&layout $=$ item\&id $=1137 \& I t e m i d=50$

Dents-Sadura A., Wspótpraca i działanie grupowe: o metodzie pedagogicznej Jacka Kuronia, w: Kuroń. Przewodnik Krytyki Politycznej, Wydawnictwo Krytyki Politycznej, Warszawa 2014.

Drucker P., Praktyka zarzadzania, MT Biznes, Warszawa 2003.

Frieske K.W., Polowanie na jednorożca: demokratyczna administracja publiczna, „Samorząd Terytorialny" 2014, nr 1-2(277-278).

Fukuyama F., Zaufanie: kapitał społeczny a droga do dobrobytu, PWN, Warszawa-Wrocław 1997.

Gardawski J., Dialog społeczny w Polsce. Teoria, historia, praktyka, MPiPS-Oficyna Wydawnicza SGH, Warszawa 2009.

Gąciarz B., Bartkowski J., Samorząd a rozwój. Instytucje - obywatele - podmiotowość, IFiS PAN, Warszawa 2012.

Growiec K., Kapitat społeczny. Geneza i społeczne konsekwencje, Wydawnictwo Szkoły Wyższej Psychologii Społecznej „Academica”, Warszawa 2011.

Habuda A., Prawo jako instrument ograniczenia patologii $w$ demokratycznym państwie prawnym, w: Patologie w administracji publicznej, red. P.J. Suwaj, D.R. Kijowski, Wolters Kluwer, Warszawa 2009.

Hausner J., Debata: Czy konieczne są systemowe zmiany w funkcjonowaniu jednostek samorzadu terytorialnego?, w: Sprawne państwo, Wydawnictwo UE w Krakowie, Małopolska Szkoła Administracji Publicznej w Krakowie, Kraków 2014.

51 P. Sztompka, Zaufanie. Fundament społeczeństwa, Znak, Kraków 2007, s. 292. 
Herman A., Konopka D., Rola zaufania w zarządzaniu wartością $w$ warunkach rosnqcej niepewności, w: Metodologiczne aspekty zarządzania wartościa przedsiębiorstwa, red. E. Urbańczyk, A. Gąsior, M. Romanowska, „Zeszyty Naukowe Uniwersytetu w Szczecinie” 2012, nr 737, „Finanse, Rynki Finansowe, Ubezpieczenia” nr 56.

Hirschman A., Against Parsimony; Three Easy Ways of Complicating Some Categories of Economic Discurse, w: Trust; Making and Breaking Cooperative Relations, red. D. Gambetta, Blackwell, Oxford 1988.

Kieżun W., Patologia transformacji, Poltext, Warszawa 2012.

Konopka D., Glokalizacja zaufania publicznego jako nowa kategoria socjoekonomiczna, „Kwartalnik Nauk o Przedsiębiorstwie” 2015, nr 3(36).

Konopka D., Kryzys zaufania a nie prawa - na przykładzie administrowania sadownictwem powszechnym w Polsce, w: Kryzys prawa administracyjnego. Inflacja prawa administracyjnego, red. P.J. Suwaj, Wolters Kluwer, Warszawa 2012.

Konopka D., Rewitalizacja zaufania do administracji publicznej w Polsce, w: Samorzadność w warunkach kryzysu, red. S. Partycki,Wydawnictwo KUL, Lublin 2013.

Krastew I., Demokracja nieufnych. Eseje polityczne, Wydawnictwo Krytyki Politycznej, Warszawa 2013.

Lewicka-Strzałecka A., Korupcja i zaufanie, http://www.annalesonline.uni.lodz.pl/archiwum/2007/2007_01_lewicka_strzalecka_211_219.pdf

Lipset S.M., Lenz G.S., Korupcja, kultura i rynki, w: Kultura ma znaczenie, red. L.E. Harrison, S.P. Huntington, Zysk i S-ka, Poznań 2003.

Majer A., Lokalność w cieniu globalizacji, „Annales Universitatis Mariae Curie-Skłodowska Lublin-Polonia" 2011, Vol. XXXVI, 2, Sectio 1.

Narastajace dysfunkcje, zasadnicze dylematy, konieczne działania. Raport o stanie samorządności terytorialnej w Polsce, Wydawnictwo UE w Krakowie, Małopolska Szkoła Administracji Publicznej w Krakowie, Kraków 2013.

Olson M., The Logic of Collective Action, Harvard University Press, Cambridge, MA 1965.

Portes A., The Two Meanings of Social Capital, „Sociological Forum” March 2000, Vol. 15, No. 1.

Praca, społeczeństwo, gospodarka. Między polityka a rynkiem, red. J. Osiński, Oficyna Wydawnicza SGH, Warszawa 2011.

Putnam R.D., Bowling Alone. The Collapse and Revival of American Community, Simon\&Schuster, New York 2000.

Putnam R., Demokracja w działaniu. Tradycje obywatelskie we wspótczesnych Włoszech, Znak, Kraków 1995.

Regulski J., Życie splecione z historia, Ossolineum, Wrocław 2014.

Sowa K.Z., Zmierzch i odrodzenie lokalizmu, w: Społeczności lokalne. Teraźniejszość i przyszłość, red. B. Jałowiecki, K.Z. Sowa, P. Dudkiewicz, IGP UW, Warszawa 1989. 
Syka M., Kuroń budzi nas do działania, w: Kuroń. Przewodnik Krytyki Politycznej, Wydawnictwo Krytyki Politycznej, Warszawa 2014.

Sztompka P., Zaufanie. Fundament społeczeństwa, Znak, Kraków 2007.

Yamigishi T., Yamigishi M., Trust and Commitment in the United States and Japan, Motivation and Emotion, 1994.

Żakowski J., Kuszenie Jacka Kuronia, „Polityka” 25 czerwca 2004, nr 26(2458).

Żuk P., Zmiana jest możliwa i konieczna, „Le Monde Diplomatique Polska”, „Dolnośląski Dodatek Kulturalny" 15 grudnia 2014, nr 2.

\section{Strony internetowe}

http://analizy.mpips.gov.pl/images/stories/publ_i_raporty/DS2013/Raport_glowny_Diagnoza_Spoleczna_2013.pdf

http://civicpedia.ngo.pl/wiadomosc/955642.html, P. Teisseyre, Łączy nas brak zaufania

http://www.cbos.pl/SPISKOM.POL/2010/K_015_10.PDF

http://www.cbos.pl/SPISKOM.POL/2012/K_033_12.PDF

http://www.cbos.pl/SPISKOM.POL/2014/K_029_14.PDF

http://wyborcza.pl/magazyn/1,142070,16971028, Tak_jestem_pryncypialny.html

\section{Ustawy}

Ustawa z dnia 18 lipca 1998 r. o ordynacji wyborczej do rad gmin, rad powiatów i sejmików województw, DzU 1998, nr 95, poz. 602.

\section{The importance of trust and cooperation in local dimensions from the perspective of 25 years of self-government in Poland}

The article attempts to examine the progress that has been made in the area of self-government over the last quarter century in Poland. Not only has the chaos in the institutional process in this period affected the overall low level of citizens' trust in democratic institutions, but it also led to absence of effective cooperation between them. The author indicates two methods of both increasing public trust in the institution and increasing effectiveness of cooperation between institutions themselves, i.e. systematic changes in the self-government and glocalization of public trust.

Keywords: cooperation, self-governance, localism, glocalization of public trust 


\section{L'importance de la confiance et de la coopération dans la dimension locale vu dans la perspective de 25 ans d'auto-gouvernance en Pologne}

Le but de cet article est de tenter d'examiner le progrès réalisé dans le domaine de la cogestion autonome des affaires par les communautés locales et régionales au cours du dernier quart de siècle en Pologne. Le chaos du processus institutionnel dans cette période-là a négativement affecté non seulement le niveau de confiance des citoyens dans les institutions démocratiques, mais aussi la coopération efficace entre eux. L'auteure indique qu'à côté de changements systémiques dans le fonctionnement de l'administration locale, qui peuvent contribuer à accroître la confiance et à améliorer la coopération de l'administration publique avec les citoyens, une direction de recherche intéressante pour restaurer la confiance dans l'administration publique en Pologne serait le domaine qu'elle définit comme la glocalisation de la confiance publique.

Mots-clés: coopération, auto-gouvernance, localisme, glocalisation de la confiance publique

\section{Важность доверия и сотрудничества на локальном уровне с точки зрения 25-летя самоуправления в Польше}

В статье предпринята попытка проанализировать прогресс, достигнутый за последние четверть века в Польше в области самостоятельного совместного управления своими делами местными и региональными общинами. Хаос институционального процесса в этот период не только повлиял на общий низкий уровень доверия граждан к демократическим институтам, но и на отсутствие эффективного сотрудничества между ними. Автор указывает на то, что кроме системных изменений в функционировании органов местного самоуправления, которые могут способствовать повышению доверия и более тесному сотрудничеству с государственной администрацией, интересным путем восстановления доверия к государственной администрации в Польше является область, определяемая как глокализация общественного доверия.

Ключевые слова: сотрудничество, самоуправление, местные интересы, глокализация общественного доверия 